\title{
Editorial: Fuchs' uveitis: from Imperial Vienna to global appraisal
}

\author{
Carl P. Herbort • Moncef Khairallah
}

Received: 4 May 2010/Accepted: 3 June 2010/Published online: 25 June 2010

(C) Springer Science+Business Media B.V. 2010

At the beginning of the last century, a uveitis entity linked to heterochromia was identified. It was first described in 1902 by Ernst Fuchs, working in Habsburg Imperial Vienna, in these terms: "When the colours of both eyes are different, it can happen that in one of the two eyes, always in the eye with the brighter iris, a cataract develops. In addition these brighter eyes present also a chronic cyclitis with corneal keratic precipitates" [1]. This observation was published in 1902 in the 9th edition of Ernst Fuchs' ophthalmology textbook (Fig. 1).

Of course heterochromia, a very obvious clinical sign, had been described much earlier. Aristotle named it heteroglaucos. A famous heterochromic in antiquity was Alexander the Great, who rode a horse, "Bukephalos", which was itself heterochromic.

In 1904, Georges Weill from Strassburg, at the time in German-ruled Alsace, described seven cases where "heterophthalmus" was associated with cataract and cyclitis with keratic precipitates (KPs). He

C. P. Herbort ( $\square)$

Inflammatory and Retinal Eye Diseases, Centre for Ophthalmic Specialized Care (COS), Clinique

Montchoisi, Lausanne, Switzerland

e-mail: carl.herb@bluewin.ch

C. P. Herbort

University of Lausanne, Lausanne, Switzerland

M. Khairallah

Department of Ophthalmology, Fattouma Bourguiba

University Hospital, Monastir, Tunisia said that he had performed a widespread literature search and had not found any previous report of this particular association, and therefore claimed that he was the first to have mentioned the association of "heterophthalmus, cataract and cyclitis" [2] (Fig. 2). Weill had not found any mention of this triad, as Fuchs' first observation was not published in a journal but in his textbook (Fig. 1). In response to Weill's article, Ernst Fuchs published an article in 1906 that is now considered the primary article on this entity (Fig. 3). The title, "About complications of heterochromia", shows that heterochromia was at the center of interest [3]. In the 15th edition of his ophthalmology textbook published in 1926 and edited by his pupil Salzmann, Fuchs gave a complete description of the features of the entity that came to be known under the eponym of "Fuchs' heterochromic cyclitis", including heterochromia, cataract, cyclitis with KPs and, most importantly, vitreous involvement (Fig. 4). He also mentioned that these eyes tolerated surgery very well [4].

Ernst Fuchs (Fig. 5) had already retired, in 1915, as Director of the Second Vienna Eye Hospital [5]. He became Director of this institution in 1885, 1 year after the Austrian ophthalmologist, Karl Koller, working at the Vienna General Hospital, had introduced cocaine as a topical anesthetic in ophthalmology. This discovery represented a tremendous leap forward for ophthalmology as it came at the start of a marvelous expansion in ocular surgery. Ophthalmology in Vienna, thanks to people like Ernst Fuchs, was then, 


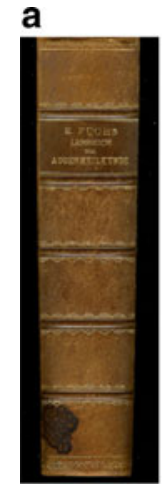

b

: In der 9. Auflage meines Lelhrbuches der Augenheilkunde, welche im Sommer 1902 erschienen ist, findet sich auf Seite 494 folgender Passus: "Wenn die beiden Augen verschiedene Farben haben (z. B. das eine braune, das endere blaue. Iris), kann es geschehen, dass in einem der beiden Angen, und zwar stets in dem helleren, sich Kataralkt entwickelt. Dies muss man, bei Abwesenheit anderer Ursachen, mit der mangelbaften Pigmentierung dieser Augen in Verbindung bringen, indem man annimnt, dass beiden Vorgängen eine Ernährungsstörung zugrunde liege. Ueber diese weiss man zwar nichts genaues; drss' sie aber vorhanden ist; erhellt daraus, dass man in solchen helloren Augen auch zuweilen chronische Cyklitis mit Prizipitaten findet. Die Kataralst in solchen Augen ist daher zu den lomplizierten Katarakten $z u$ rechnen."

Fig. 1 First mention of the association of heterochromia, cataract and cyclitis. a Hard cover of 9th edition of Ernst Fuchs' textbook published in 1902, where the triad of heterochromia, cataract and cyclitis was mentioned for the

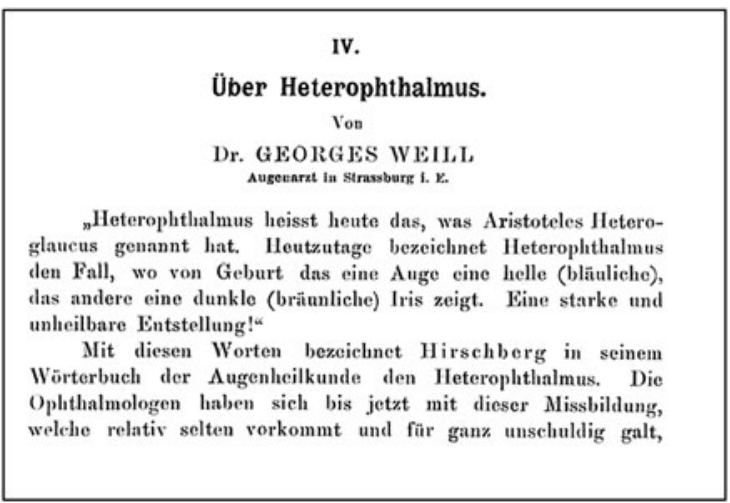

Fig. 2 Title of Weill's article, who was thought to be the first to describe the association of heterochromia, cataract and cyclitis

in parallel with German medicine, at its apogee and at the heart of medical progress [6]. Therefore, descriptions of disease entities which reflected the pathology found in a caucasian population were then diffused to the rest of the world through translations of leading ophthalmology textbooks. Fuchs' textbook of ophthalmology was translated into French, Russian, Japanese, Chinese, Spanish and Italian as well as going to ten British and American editions [5]. Heterochromia in Fuchs' uveitis illustrates this process very well, as it even found its way into the disease eponym.

Heterochromia was to Fuchs' uveitis what poliosis was to Vogt-Koyanagi-Harada disease. It was the flashy sign that first attracted the attention of clinicians but later functioned as the tree which prevents the forest being seen. first time. b In his 1906 article, Fuchs cites the text of the 1902 edition of his textbook on the triad of heterochromia, cataract and cyclitis

a

Originalarbeiten.

I.

Ueber Komplikationen der Heterochromile. Von

Prof. Dr. ERNST FUCHS

in Wien.

(Mit 3 Figuren in Texte.)

b

Im XI. Bande der Zeitschrift fŭr Augenheilkunde, welclier in der ersten Halfte des Jahres 1904 herauskam, yeröffentlicht Weill eine Arbeit über Heterophthalmus, in welcher er 7 Fälle beschreibt, bei denen auf dem Ange mit dér helleren Trís Katarakt und gleichzeitig Cyklitis vorhanden war. Er ist der Meinung, als erster dieses. Zusammentreffen beobachtet zu haben und sagt ausdrücklich, dass er etwa.20 verschiedene Lehrbũcher der Augenheilkunde daraufhin nachgeschen habe, ohne etwas $z u$ finden. Vermutlich hatte er von meinem Lohrbuche, vorausgesetat, dass er es nachgesehen hat, nicht die damals neueste Auflage zar Hand genommen.

Wenn ich jetzt über diese Fülle das Wort ergreife, so geschieht es weniger zur Wahrung der Prioritat, als weil ich ein grōsseres Material gesammelt und einige anatomische Untersachungen angestellt habe.

Zoitechrift tar Angentioflendo. Ba. Xv. Heft 2.

14

Fig. 3 Primary article on Fuchs' uveitis published in 1906. a Title of article. b Part of the text in his 1906 article where Fuchs explains that he, and not Georges Weill, was the first to publish the association of heterochromia, cataract and cyclitis, in his 1902 textbook

Indeed the strong position of heterochromia in early-phase disease definitions in caucasian populations with bi-colored irises later hampered the proper recognition of the reality of the disease. In populations with brown irises, heterochromia is always absent and discrete structural iris changes have to be searched for instead. This led to underdiagnosis of the 
a

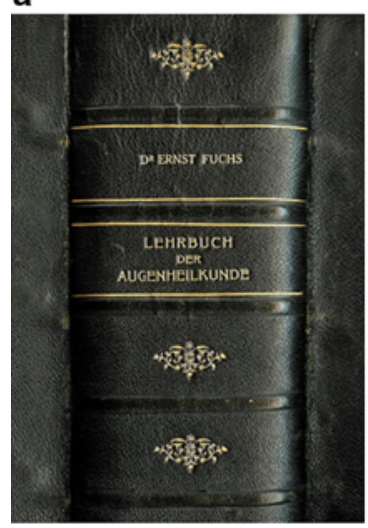

b

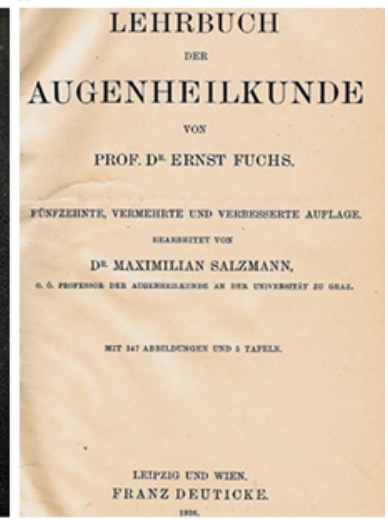

C

12. Zyklitis bei Heterochromie. Diese Krankheit, welche nur auf dem helleren Auge auftritt (§331), ist immer eine reine Zyklitis, d. h. sie äußert sich nur durch feine graue Präzipitate und zarte fädige oder flockige Trübungen im vorderen Abschnitte des Glaskörpers. Die Iris zeigt nicht die geringsten Entzündungserscheinungen, sondern nur die in §331 erwähnten Struktureigentümlichkeiten. Diese Krankheit verläuft röllig ohne Reizerscheinungen; auch bei längerer Untersuchung tritt keine Ziliarinjektion ein und operative Eingriffe werden ebensogut vertragen wie von einem völlig. gesunden Auge. Weiterhin kommt es zu Linsentrübung $(\S 457)$.

Fig. 4 The clinical description of Fuchs' uveitis is complete in the 15th edition of his textbook published in 1926. a Hardcover. b Title page. c Detailed description of the clinical entity, clearly citing the vitreous involvement

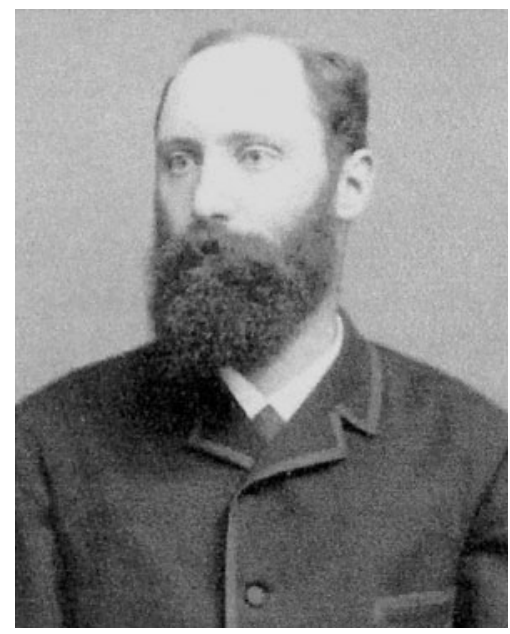

Fig. 5 Portrait of Ernst Fuchs at the start of his career (taken from reference 5)

disease as clinicians were searching for heterochromia, wrongly considered to be a disease-defining feature, but which was not present in brown iris populations. This is a strong reason to change the eponym of the disease to "Fuchs' uveitis" instead of Fuchs' heterochromic cyclitis.

After the clear description of vitreous involvement by Fuchs, another drift occurred. The articles and textbooks gradually forgot the posterior segment involvement and Fuchs' uveitis came to be known as an anterior uveitis, again probably because the very particular aspect of the typical Fuchs' KPs attracted and monopolized the attention of clinicians. Vitreous features were pushed into the background and intermediate uveitis as a differential diagnosis was no longer cited. The consequence was that clinicians were surprised when they saw Fuchs' patients with vitritis and this led to misdiagnosis and diagnostic delay [7]. In a recent article it was clearly shown that the most frequent clinical feature present was inflammatory vitreous involvement, found in almost $100 \%$ of cases [8]. Clearly vitritis has to be put back into the limelight to drastically reduce misdiagnosis and diagnostic delay. The other feature which has not sufficiently been put forward and should replace the quest for heterochromia in patients with brown irises is the fine analysis of structural changes of the iris in the Fuchs' eye as compared to the other eye.

In this issue, an article analyzing fluorescein angiographic findings in Fuchs' uveitis broadens our knowledge of the disease [9]. The authors showed that in almost $100 \%$ of Fuchs' patients where a fluorescein angiography had been undertaken for diagnostic purposes in non-diagnosed cases, disc hyperfluorescence was detected which added to the confusion of the clinician who was not aware of this feature. This study also showed that in $100 \%$ of these cases no cystoid macular edema (CME) was detected despite years of inflammation, as long as the eyes had never undergone surgery. In contrast, Fuchs' eyes after (cataract) surgery were no longer protected and CME was detected in some of them. Such a finding represents an important additional feature to define Fuchs' uveitis, although there may be a bias towards overemphasis of disc hyperfluorescence as possibly only more severe cases have had an angiography performed. The vitreous and disc involvement tends to show that the disease is not a cyclitis but a uveitis involving other structures. This is the second reason to abandon the term cyclitis and to turn to the eponym "Fuchs'uveitis" as indicated above.

Another interesting article on Fuchs' uveitis coming from a "brown-eyed area", Saudi Arabia, is 
included in this issue [10]. It shows that heterochromia is very rare but that iris strucure changes in the Fuchs' eye were present in close to $100 \%$ of cases. Other articles coming from brown-eyed areas tend to show that when readjusted criteria are used and heterochromia is downplayed as a diagnostic criterion, the rate of Fuchs' uveitis is comparable in most parts of the world, reaching the considerable percentage of $5-10 \%$ of total uveitis cases [11-15].

Because Fuchs' uveitis is ubiquitous and represents such a high proportion of uveitis cases all over the world, it is important to define more global diagnostic criteria in order to decrease the diagnostic problem that this disease still causes. Major features such as vitritis, typical stellate retrodescemetic KPs, iris structure changes, absence of CME and absence of synechiae should be considered.

Confirmatory signs such as heterochromia, presence of lens opacification, presence of hypertrophic vessels in the irido-corneal angle and presence of disc hyperfluorescence should also be listed. New guidelines regarding diagnostic criteria for Fuchs' uveitis are certainly needed and should be generated in an international workshop on Fuchs' uveitis, similar to what has been achieved for ocular sarcoidosis (IWOS) [16]. In this way misdiagnosis and diagnostic delays, sometimes the cause of deleterious effects and unnecessary immunosuppressive therapy, can in future be avoided in an increasing number of cases [7].

Recently evidence has been reported that rubella virus particles have been identified by PCR in intraocular samples from Fuchs' eyes, giving more credit to an infectious rather than a inflammatory/degenerative cause for Fuchs' uveitis [17, 18]. These new elements are not contradictory, as an infectious trigger has long been thought to be at the origin of a subsequently auto-maintained inflammation in Fuchs' uveitis, and they do not fundamentally change the appraisal of Fuchs' uveitis.

\section{References}

1. Fuchs E (1902) Lehrbuch der Augenheikunde, 9th edn. Franz Deuticke, Leipzig \& Vienna, p 494
2. Weill G (1904) Ueber Heterophthalmus. Zeitschrift für Augenheilkunde 11:165-176

3. Fuchs E (1906) Ueber Komplikationen der Heterochromie. Zeitschrift für Augenheilkunde 15:191-212

4. Fuchs E (1926) Lehrbuch für Augenheilkunde, 15th edition, Franz Deuticke, Leipzig \& Vienna, p 471

5. Müller A, McGhee CNJ (2003) Professor Ernst Fuchs (1851-1930). A defining career in ophthalmology. Arch Ophthalmol 121:888-891

6. Albert DM (1996) The development of ophthalmic pathology. In: Albert DM, Edwards DD (eds) The history of ophthalmology. Blackwell Science, Oxford, pp 87-89

7. Herbort CP, Bouchenaki N (2009) Fuchs' uveitis. In: Gupta A, Gupta V, Herbort CP, Khairallah M, Uveitis (eds) Text and imaging. Jaypee Brothers, New Dehli, pp 321-330

8. Bouchenaki N, Herbort CP (2009) Fuchs' uveitis: failure to associate vitritis and disc hyperfluorescence with the disease is the major factor for misdiagnosis and diagnostic delay. MEAJO 16:239-244

9. Bouchenaki N, Herbort CP (2010) Fluorescein angiographic findings and clinical features in Fuchs' uveitis. Int Ophthalmol 30. doi:10.1007/s10792-010-9366-z

10. Al-Mansour YS, Al-Rajhi AA, Al-Dhibi H, Abu El-Asrar AM (2010) Clinical features and prognostic factors in Fuchs' uveitis. Int Ophthalmol 30. doi:10.1007/s10792010-9379-7

11. Tran VT, Auer C, Guex-Crosier Y, Pittet N, Herbort CP (1994) Epidemiology of uveitis in Switzerland. Ocul Immunol Inflamm 2:169-176

12. Cimino L, Aldigeri R, Salvarani C, Zotti CA, Boiardi L, Parmeggiani M, Casali B, Cappucini L (2010) The causes of uveitis in a referral centre of Northern Italy. Int Ophthalmol 30. doi:10.1007/s10792-010-9359-y

13. Yang P, Zhang Z, Zhou $\mathrm{H}$ et al (2005) Clinical patterns and characteristics of uveitis in a tertiary center for uveitis in China. Curr Eye Res 30:943-948

14. Soheilian M, Heidari K, Yazdani S, Shahsavari M, Ahmadieh H, Dehghan MH (2004) Patterns of uveitis in a tertiary eye care center in Iran. Ocul Immunol Inflamm 12:297-310

15. Khairallah M, Ben Yahia S, Ladjimi A, Messaoud R, Zaouali S, Attia S, Jenzeri S, Jelliti B (2007) Pattern of uveitis in a referral centre in Tunisia, North Africa. Eye 21:33-39

16. Herbort CP, Rao NA, Mochizuki M, Members of the Scientific Committee of the First International Workshop on Ocular Sarcoidosis (2009) International criteria for the diagnosis of ocular sarcoidosis: results of the first International Workshop on Ocular Sarcoidosis (IWOS). Ocul Immunol Inflamm 17:160-169

17. Quentin CD, Reiber H (2004) Fuchs heterochromic cyclitis: rubella virus antibodies and genome in aqueous humor. Am J Ophthalmol 138:46-54

18. Siemerink MJ, Sijssens KM, de Groot-Mijnes JD, de Boer JH (2007) Rubella virus-associated uveitis in a nonvaccinated child. Am J Ophthalmol 143:899-900 